\title{
'n Opstanding met verheerlikte liggame in Matteus 27:51b-53? 'n Noukeurige lees van die teks
}

S P Botha

Universiteit van die Noorde: Qwaqwa-tak

\begin{abstract}
A glorified bodily resurrection in Matthew 27:51b-53? A close reading of the text

Matthew 27:51b-53 is a crux interpretum in the exegesis of the Matthew text. By comparing the semantic domains of lexical items and by determining the subtle distinctions between closely related words, the article takes a close look at the reading of this text. The text is interpreted within its narrative context against the background of the apostolic preaching tradition. Following these exegetical lines, the article makes the point that the resurrection of the saints in Matthew 27:51b-53 is to be understood as a glorified bodily resurrection.
\end{abstract}

\section{INLEIDING}

Die problematiese verwysing na die 'opstandings'-gebeurtenis in Matteus 27:51b-53 maak hierdie gedeelte 'n crux interpretum van die studie van die Matteusevangelie. Witherup (1987:574) gee die volgende opsomming van verskillende interpretasies wat al aan hierdie gedeelte gegee is: Some scholars have tried to show how the passage de-

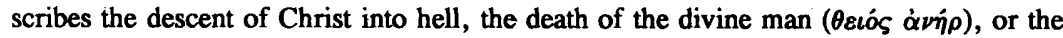
death of the cosmic deity. Others have seen in it a displaced resurrection narrative (Hutton), an ancient Jewish apocalyptic hymn (Schenk), a polyvalent passage with confessional, salvation-historical, and soteriological implications (Senior), or a fulfillment of the vision of Ezekiel 37:1-4 (Monasterio; vgl ook Senior 1976:312-313).

Meeste van hierdie benaderings het in gemeen die gebruik van histories-kritiese, tradisie- en redaksie-historiese oorwegings wat baie energie verbruik op gegewens buite die teks om daarmee te probeer lig werp op die teks self. Met inagneming van enkele gegewens verkry uit bogenoemde oorwegings wil hierdie artikel konsentreer op die noukeurige lees van die teksgedeelte self deur die vergelyking van die semantiese velde van leksikale items en die vasstelling van subtiele betekenisverskille tussen nouverwante woorde. Nadat die betroubaarheid van die Griekse teks van die perikoop tekskrities geèvalueer is, en vanuit bronkritiese en tekstuele verbande ondersoek gedoen is na die die teks in terme van die struktuur en styl van die Matteusevangelie asook na terme van 
die apostoliese verkondigingstradisie insake die liggaamlike opstanding van Jesus en van gelowiges in die algemeen, sal eksegetiese oorwegings voorrang geniet by 'n noukeurige lees van die Griekse teks van Matteus 27:51b-53. Die teks sal binne die narratiewe konteks van Matteus en binne die konteks van die apostoliese verkondigingstradisie waarbinne dit tot stand gekom het, geinterpreteer word.

\section{TEKS- EN BRONKRITIESE AANMERKINGS}

Tekskrities staan die lesing van Matteus 27:51b-53 vas, behalwe dat daar 'n swak betuigde teksvariant is vir $\dot{\eta} \gamma \varepsilon \hat{\rho} \rho \eta \eta \alpha \nu$, naamlik die grammaties meer korrekte derde persoon enkelvoud $\dot{\eta} \gamma \varepsilon \dot{\rho} \rho \theta \eta$ as werkwoorduitgang van die neutrum meervoud.

Harris (1983:243-244; vgl ook Wenham 1981:150-152) wil die punktuasie van die gedeelte soos volg verander:

If a full stop is placed after 'the tombs were opened' ( $v$ 52a), both the resurrection and appearance of the 'saints' took place after Jesus' resurrection. But if we place a full stop after 'many bodies ... were raised' ( $v$ 52) and construe 'after his resurrection' (v 53) solely with what follows ('they entered the holy city'), the resurrection and exit of the 'saints' from their tombs occurred on Good Friday, but their appearances after Easter.

Pogings om die punktuasie te verander, veral volgens die voorbeeld van Harris, erken dat dit hier gaan om die opstanding van persone, maar het ten doel om sowel die opstanding van hierdie persone as hulle verskyning ná die opstanding van Jesus te plaas ten einde nie in stryd met 1 Korintiërs 15:20 hulle opstanding voor die opstanding van

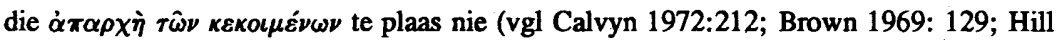
1972:356; Schweizer 1975:516). Dit is egter beter om te hou by die meer natuurlike punktuasie van die Nestle- en UBS-tekste waarvolgens verse 51 tot 53 een sin vorm. Indien die opstanding van hierdie persone verstaan sou word as 'n gebeure wat ná die opstanding van Christus plaasgevind het, dan sou ten opsigte van die tekens wat tydens die kruisgebeure plaasgevind het, hierdie teken die enigste wees wat uitgestel is tot na die opstanding van Jesus. Die ander het plaasgevind by die moment van Jesus se sterwe.

Wanneer 1 Korintiërs 15:20 en 23 insake Christus as die $\dot{\alpha} \pi \alpha \rho \chi \grave{\eta}$ deur eksegete gebruik word by die uitleg van Matteus 27 as tydsordelike argument vir die verwerping van die beskouing dat die persone van Matteus 27 wel opgewek is voordat Christus 
opgestaan het, hoewel hulle volgens vers 28 eers na Jesus se opstanding in Jerusalem ingegaan en aan baie mense verskyn het, sou teen hierdie tydsordelike argument aangevoer kan word dat Jesus se versoeningswerk en oorwinning oor die dood in elk geval reeds terugwerkend tot heil was vir Ou-Testamentiese vromes. In die verband kan verwys word na Jesus se Skrifbewys aan die Sadduseërs vir die opstanding met sy verwysing na Abraham, Isak en Jakob (Eks 3:6, 15, 16) as lewend (Matt 22:32 en parallelle), asook die Ou-Testamentiese tradisie dat Henog en Elia nie gesterf het nie maar lewend na die hemel opgeneem is (Gen 5:24, 2 Kon 2:11), maar dan nadat ook hulle bes moontlik eers 'verander' ( 1 Kor 15:51) was, soos dit eendag sal gebeur by die 'hemelvaart' (1 Tess 4:17) van die gelowiges wat nog sal lewe by die wederkoms van Christus. Die tydordelike verklaring gee dus nie finale uitsluitsel oor die tyd wanneer die persone opgewek is nie, aangesien die dood en latere opstanding van Christus nog steeds die basis kan wees op grond waarvan ook diegene van Matteus 27 opgewek is. Bowendien verwys 1 Korintiërs 15:23 binne die konteks van hierdie hoofstuk vooruit na Christus as die $\dot{\alpha} \pi \alpha \rho \chi \grave{\eta}$ in verband met al diegene wat in die toekoms opgewek sal word by sy (weder-)koms (vgl Hendriksen 1973:975).

Bronkrities behoort hierdie perikoop tot die narratiewe materiaal van Matteus wat nie tuis te bring is onder die versamelings (indien dit wel as sodanig bestaan het) van die gesegdes eie aan Matteus, die testimonia en sy geboorteverhale nie (vgl Guthrie 1970:157-167). Hierdie perikoop word deur geleerdes geplaas onder Matteus se sogenaamde ander narratiewe materiaal. Baie geleerdes het gemeen om 'n mate van gelyksoortigheid by hierdie ander groep vertellings te bespeur as aanduiding van 'n gemeenskaplike bron. Die karakteristieke kenmerke wat hierdie materiaal sou saambind is, 1) stilistiese kenmerke; 2) verwysings na engele en profesie; 3) 'n beklemtoning van wonders; en 4) 'n dogmatiese benadering om die vroeë tradisies te ondersteun.

Volgens Guthrie (vgl 1970:166-167) kan nie veel waarde geheg word aan gemeenskaplike stilistiese kenmerke nie omdat daar nie genoeg onderskeidende eienskappe is wat hierdie narratiewe sou kon kenmerk as stilisties verskillend van die res van die Evangeliemateriaal nie.

Belangstelling in engele is nie beperk tot die ander narratiewe materiaal nie, behalwe vir die uitdrukking 'Engel van die Here' (Matt 1:24 en 28:2) wat net by hierdie 'bron' voorkom. Sowel Markus as Lukas het verwysings na engele wat daarop dui dat dit 'n algemene eienskap van die vroeë tradisie was.

Die profetiese element is wel sterker by Matteus as by die ander Sinoptiese Evangelies, maar dit is ongetwyfeld te danke aan sy doelstelling om met sy evangelie te bewys dat Jesus wel die Christus is, die vervuller van die Ou-Testamentiese profesië. Dié Evangelie bevat ten minste veertig aanhalings wat direk uit die Ou Testament herlei kan word (Hendriksen 1973:80-82). 
Dit is waar dat die wonderelement meer beklemtoon word in Matteus as in die ander evangelies, maar sy aanbieding is baie beskeie en sober wanneer dit vergelyk word met die bonatuurlike aandikkings en optooisels van die apokriewe evangelies, en is dit ongeregverdig om hierdie sogenaamde ander narratiewe materiaal van Matteus as 'apokrief' te takseer (Guthrie 1970:166-167). Indien die wonderelement as sodanig die rede is vir geleerdes om hierdie materiaal as apokrief te tipeer, dan lê die probleem by 'n persoonlike vooronderstelling waarmee moderne navorsers hierdie stof benader, en is dit vir die doel van hierdie bespreking nie ter sake vir die eksegese van die Griekse teks van Matteus 27:51b-53 nie.

Indien Matteus 27:51b-53 ook bedoel was om steun te gee aan bepaalde bestaande tradisies binne die vroeë kerk, byvoorbeeld die vervulling van die profesie van Esegiël 37 , dan maak die feit van steungewing as sodanig nog nie die vertelling outomaties dogmaties in die sin van histories onbetroubaar nie.

\section{TEKSTUELE VERBANDE}

\subsection{Narratiewe posisie van Matteus 27:51b-53 binne die evangelie}

Hierdie perikoop vorm deel van 'n groter narratiewe eenheid naamlik, Matteus 26-28 (vgl Riekert 1982b:125, 128). Binne hierdie narratiewe eenheid volg die gebeure van die perikoop onder bespreking op die kruisigingsgebeure van Matteus 27:33-50 (Riekert 1982a:67-69) en loop dit dan uit op die belydenis van die Romeinse offisier en sy soldate.

Senior (1976:321, 324-325) toon aan die hand van redaksie-historiese oorwegings aan dat hoofstuk 27:51 b-53 as deel van die addisionele materiaal van Matteus (in vergelyking met die Markustradisie) volkome inpas by die komposisie van die Matteusevangelie asook by Matteus se doel met die evangelie (vgl ook Witherup 1987:579). Matteus het dus hierdie passasie self geskryf. Matteus volg die basiese profiel van Markus van bespotting (Matt 27:38-44), dood (Matt 27:45-50) en reaksie (Matt 27:51-56), maar doen die nodige by werking by elke fase van die skema ooreenkomstig sy eie doelstelling met die evangelie. Witherup (1987:575-578) toon aan die hand van 'n narratiewe analise van die ontwikkeling van die plot aan dat daar ' $n$ kontinue progressie is vanaf Matteus 27:1 totdat die klimaks van die hoofstuk bereik word in verse 51 tot 54 . Hy konkludeer soos volg: "The narrowing of the temporal sequence and the heightened divine eschatological happenings establish the climactic nature of the death scene. In short, the correct interpretation of 27:51-54 ... hinges on this structure' (Witherup 1987:578). Matteus 27:51b-53 pas dus volkome in by die komposisie en plot van die Matteusevangelie. Dit verskaf nog 'n rede waarom dit nie beskou kan word as 'n latere 'apokriewe' toevoeging nie (vgl Afd 2 hierbo). 
Diskoersanalities skakel die verskillende episodes van hierdie narratiewe passasie onderling soos volg:

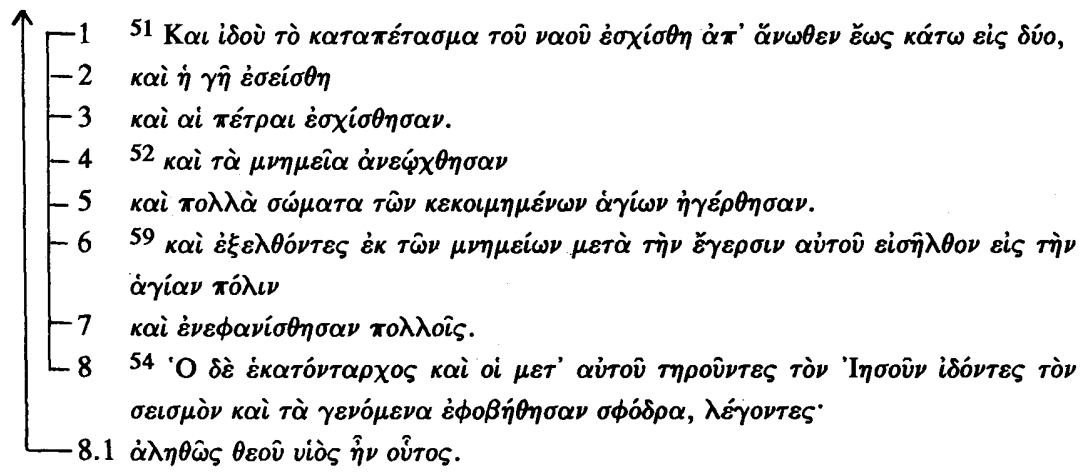

In bostaande perikoop staan kola 1 tot 7 in 'n neweskikkend-additief-verskillende en opeenvolgende verhouding tot mekaar (vgl Nida et al 1983:102), telkens verbind deur die konnektiewe $\alpha \alpha i$ in 'n parataktiese kombinasie waarin die episodiese ontwikkeling en semantiese gewig van individuele gebeure van groter belang is as die onderlinge verwantskap van kola of nukleêre strukture (vgl Nida et al 1983:137). Hierdie is die tipiese diskoersanalitiese struktuur van 'n narratief. Witherup (1987:578) sê: 'The composition of this passage, with its paratactic style, use of divine passives, and eyen similar sounding words, helps to reinforce the breathtaking sense of this scene, punctuating the narrative in staccato style'.

Die standpunt van Schenk dat die parataktiese styl dui op 'n Joods-apokaliptiese himne gewortel in Joodse spekulasie op die opstandingsmotief van Esegiël 37 (vgl ook Senior 1976:318), oortuig nie aangesien ander skrywers (vgl Joël 2:10, 3:4, Am 8:910, Op 6:12-14; 11:17-19, 16:18-21), sowel as Matteus self (vgl Matt 7:25, 27), meermale van hierdie styl gebruik maak om 'n reeks gebeure te beskryf wat in vinnige opeenvolging plaasvind, en dit doen deur werkwoorde en frases in parataktiese styl in te ryg (Senior 1976:319-320).

Oorhoofs gesien is kolon 8, wat die reaksie weergee van die Romeinse offisier en soldate, waarskynlik nie 'n direkte reaksie op die skeur van die tempelgordyn en die oopgaan van die grafte nie aangesien die offisier en soldate waarskynlik nie op daardie stadium reeds daarvan kennis kon gehad het nie. Dit was eerder 'n direkte reaksie op die verbasende gedrag van Jesus tydens die kruisgebeure en die gepaardgaande natuurgebeure, die duisternis en die aardbewing. Hoewel $\delta \grave{\varepsilon}$ bloot as 'n konnektiewe voegwoord gebruik kan word, word die gedrag van die offisier hier deur Matteus gekon- 
trasteer met dié van die skrifgeleerdes en die familiehoofde en word $\delta \grave{\varepsilon}$ hier volgens sy adversatiewe betekenis aangewend (Andt \& Gingrich 1957:170, Louw \& Nida 1988a: \$89.124). In teenstelling tot die skrifgeleerdes en die familiehoofde wat spot met die gedagte dat Jesus die Seun van God sou wees, bely die heidense Romeine hom wel as Seun van God (Witherup 1987:583). Vanuit die hoek van die narratiewe progressie gesien bereik die kruisigingsgebeure in kolon 8 sy klimaks (Witherup 1987:578-579). Kolon 8 skakel egter ook baie nou met die voorafgaande kola 1 tot 7 . Nadat dus diskoersanalities aangetoon is dat die perikoop onder bespreking inpas by die res van die kruisgebeure (nog ' $n$ argument waarom dit nie beskou kan word as 'n latere 'apokriewe' toevoeging nie), sal vir die doeleindes van hierdie artikel in hoofsaak gefokus word op die betekenis van kola 2 tot 7 .

\subsection{Die verkondigingstradisie insake die liggaamlike opstanding van Jesus en van gelowiges}

Die liggaamlikheid van Jesus se opstanding word duidelik betuig deur Jesus se lering volgens die evangeliste (vgl Botha 1991:79-86 insake die betekenis van Luk 24:37-43; Joh 2:19-22; 20:17a, 19-20, 27-28), die omstandigheidsgetuienis insake die leë graf, die weggerolde steen en die grafdoeke (Botha 1991:86-90), asook die getuienis van Lukas in Handelinge insake die vroeë kerklike tradisie (vgl Botha 1991:90-92 vir die betekenis van Hand 2:29-31, 10:41, 13:35-37).

Dit is duidelik uit Handelinge dat in die verkondigingstradisie die opstanding van Jesus hand aan hand gegaan het met die verkondiging van die toekomstige opstanding van die gelowiges ( $v g l$ Hand 4:2; 17:18 en 32; 23:6, 24:15; 21, 26:23). Die noue verband in die verkondiging tussen die opstanding van Jesus en die opstanding van dié wat aan Hom behoort maak dit meer as waarskynlik dat die opstanding van die gelowiges verwag is om ook liggaamlik te wees soos dié van Jesus. Aangesien die apostels verkondig het dat 'die opstanding uit die dood deur Jesus se opstanding 'n werklikheid geword het' (Hand 4:2, NAV), is die gelowiges se opstanding uit die dood dus verkondig as iets wat gerealiseer het, en in en deur Jesus se opstanding 'n werklikheid geword het toe Jesus opgestaan het (vgl De Villiers 1977:83-84; Grosheide 1962:62; Lenski 1934:154).

Gevolglik het Jesus se opstanding die teenwoordigheid en werklikheid van die eskatologiese opstanding van die gelowiges ingelei. Dit verklaar ook die heftige reaksie van die Sanhedrin, waarvan die Sadduseërlede die meerderheid was, teen die opstandingsprediking van die apostels. Die lede van die Sanhedrin het immers geweet dat die Fariseërs ook 'n opstanding uit die dood verwag en verkondig, maar 'es ist erst etwas anderes, ob die Auferstehung am Ende der Tage theoretisch behauptet oder ob sie aus- 
gerechnet an Jesus ... als gegenwärtige Wirklichkeit bezeugt wird' (De Boor 1973:94; vgl ook De Villiers 1977:83-84). Ander gedeeltes van die verkondigingstradisie wat moontlik ook implisiet die liggaamlike opstanding van gelowiges veronderstel, is Johannes 5:28-29 en 11:23-26.

\section{DIE BETEKENIS VAN MATTEUS 27:51b-53}

\subsection{Eksegetiese kwelvrae}

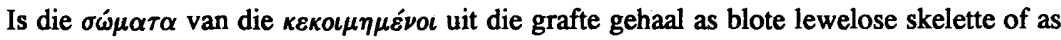
lewelose skelette oorgetrek met vleis? Of het hulle uit die grafte gegaan as lewendes met natuurlike, maar nog steeds sterflike liggame, soos dié waarmee onder andere Lasarus uit die dood opgewek is? Of het hierdie gestorwenes opgestaan met verheerlikte liggame soortgelyk aan die van die Here Jesus by sy opstanding? Wie is hierdie $\dot{\alpha} \gamma \iota \iota$ ? Waar het hulle vertoef tussen die tyd van hulle opstanding en hulle verskyning

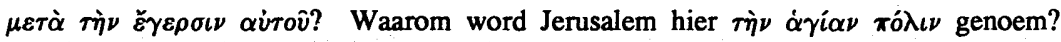
Wat word met غं $\nu \varepsilon \phi \alpha \nu i \sigma \theta \eta \sigma \alpha \nu$ bedoel?

Grosheide (1954:439) volstaan met 'n non liquet, maar waag nogtans 'n mening:

Het gaat hier niet om een eigenlijke opstanding, maar om het feit, dat God ten einde de grote betekenis van het sterven (niet van de opstanding) van Christus te openbaren, voor een tijd de lichamen van vromen uit de aarde, die door de aardbeving gespleten werd, nam en aan velen vertoonde.

Dit skyn asof Grosheide bedoel dat God lewelose liggame vertoon het aan sekere mense, aangesien dit nie hier gaan om 'een eigenlijke opstanding' nie. Dit is nie duidelik of hy bedoel dat dit net die skelette of oorblyfsels van die ontslapenes se liggame was, en of dit hulle gebeente oorgetrek met vleis was nie.

\subsection{Die aard van Jesus se opstandingsverkynings}

In die evangelies en Handelinge word die volgende twee woorde vir Jesus se opstan-

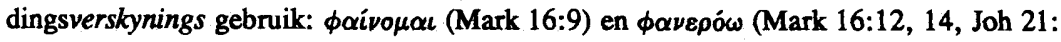
$1,14)$. 'E $\mu \phi \alpha \nu i \zeta \omega$ kom drie keer in die evangelies en Handelinge voor, naamlik in Matteus 27:53 ten opsigte van die liggame van ontslape vromes, en in Johannes 14:21 en 22 ten opsigte van Jesus se stelling dat Hy Homself aan diegene wat sy gebooie bewaar sal $\dot{\varepsilon} \mu \phi \alpha \nu i \zeta \varepsilon \imath \nu$. Die predikatiewe gebruik van die adjektief $\dot{\varepsilon} \mu \phi \alpha \nu \eta \dot{\zeta}$ (derivatief van $\dot{\varepsilon} \mu \phi \alpha v^{\prime}(\omega)$, saam met die kopulatief $\gamma \varepsilon \nu \varepsilon \dot{\sigma} \sigma \alpha \boldsymbol{\alpha}$ in Handelinge 10:40, word ook vir die opstandingsverskyning van Jesus gebruik. 
Die twee betekeniskomponente en die moontlike vertalingsekwivalente van $\phi \alpha \nu \varepsilon-$ pów in die Nuwe Testament is soos volg (Louw \& Nida 1988a):

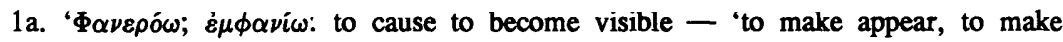
visible, to cause to be seen" ( $\$ 24.19)$;

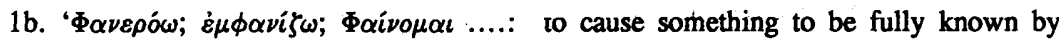
revealing clearly and in some detail - 'to make known, to make plain, to reveal, to bring to the ligth, to disclose, revelation" (\$28.36);

Die drie betekeniskomponente en die moontlike vertalingsekwivalente van $\Phi \alpha i \nu o \mu \alpha \iota$ is soos volg (Louw \& Nida 1988a):

2a. 'to become visible to someone - 'to appear, to become visible" ( $\$ 24.18)$;

2b. kyk $1 \mathrm{~b}$ hierbo ( $\$ 28.36)$;

2c. 'to make known only the superficial and not the real character of something - 'to appear to be (something), to give an impression of' (\$28.55).

Die betekeniskomponente van $\dot{\varepsilon} \mu \phi \alpha \nu i \zeta \omega$ en die vertalingsekwivalente daarvan is soos volg:

3a. Kyk 1a hierbo (\$24.19);

3b. Kyk 1b hierbo (\$28.36);

3c. 'to reveal something which is not generally known - 'to tell, to inform, to report"' (Louw \& Nida 1988a: \$33.208);

3d. 'to make a formal report before authorities on a judicial matter - 'to bring charges, to accuse formally" (Louw \& Nida 1988a:\$56.8).

Die twee betekeniskomponente en die moontlike vertalingsekwivalente van die adjektief $\dot{\varepsilon} \mu \phi \alpha \nu \dot{\eta} \zeta$ is soos volg (Louw \& Nida 1988a):

4a. '(derivative of $\dot{\varepsilon} \mu \phi \alpha \nu i \omega$ 'to make visible"' (kyk la bo) pertaining to that which has been made visible - 'visible, seen" (\$24.22);

4b. 'pertaining to not having been known before but having become evident - 'well known, evident” (\$28.35).

Die tekstuele konteks bepaal watter betekeniskomponent van 'n leksikale eenheid inpas in 'n bepaalde semantiese veld (vgl Louw \& Nida 1988a.ix). In Markus 16:12 en 14 
van die lang Markusslot, wat as teksgetuie gebruik kan word om die betekenis van

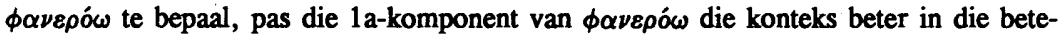
kenis van Jesus wat Homself laat sigbaar word het vir sy volgelinge. Die 1b-komponent het volgens Louw en Nida in alle gevalle te doen met 'n verskuiwing van die sensoriese domein van waarneming na die kognitiewe domein van iets volledig bekend, duidelik en helder verstaanbaar maak (Louw \& Nida 1988a:\$28.36). Uit Lukas 24 is dit duidelik dat Jesus wel na sy verskynings, sowel aan die Emmausgangers as aan sy dissipels, breedvoerig die betekenis van sy sterwe en opstanding verduidelik het. Die kognitiewe aspek was egter iets wat later en bykomend tot sy sensoriese sigbaarmaking gekom het.

Dieselfde argument geld ten gunste van die gebruik van die 1a-komponent van

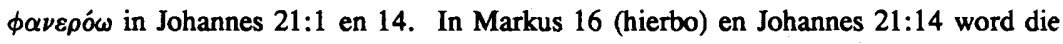
passiewe vorm van $\phi \alpha \nu \varepsilon \rho o ́ \omega$ gebruik. Hoewel dit as 'n passivum divinum vertaal sou kon word, is dit egter meer waarskynlik dat dit vertaal moet word in die aktiewe betekenis van die werkwoord (vgl Du Toit 1989:326-327), van Jesus wat Homself sigbaar

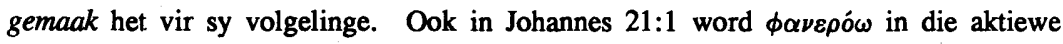
werkwoordvorm gebruik met die betekenis van Jesus wat Homself sigbaar gemaak het aan die dissipels.

In Markus 16:9 is dit die 2a-komponent van $\phi \alpha i \nu o \mu \alpha i$ wat die beste pas by die teks tuele konteks, naamlik in die betekenis van Jesus wat Homself sigbaar gemaak het aan die vroue na sy opstanding. Die $2 b$-komponent val buite die semantiese veld om die-

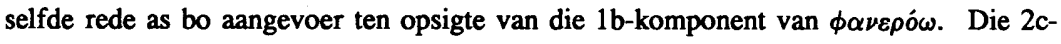
komponent val ook buite die betekenisveld van die konteks aangesien dit nie in Markus 16 gaan om 'n Jesus wat slegs gelyk of voorgekom het asof hy opgestaan het nie, maar om Jesus wat lewend ( $v 11$ ) geword het en wat sy dissipels juis verwyt het vir hulle ongeloof in die werklikheid van sy opstanding (v 14).

Hoewel die werkwoord $\dot{\varepsilon} \mu \phi \alpha \nu i \zeta \omega$ nie vir Jesus se opstandingsverskyninge gebruik word in die evangelies en Handelinge nie, word $\dot{\varepsilon} \mu \phi \alpha \nu \dot{\eta}$, die predikatiewe adjektief van $\dot{\varepsilon} \mu \phi \alpha \nu i \zeta \omega$, wel in Handelinge 10:40 vir die opstandingsverskyning van Jesus gebruik. Die $4 \mathrm{~b}$-betekenis pas nie in by die tekstuele konteks nie omdat dit nie hier gaan om Jesus wat tevore aan die dissipels onbekend was en nou bekend geword het nie. Dus is die betekenis wat pas ook hier dié van Jesus wat Homself sigbaar gemaak het net aan diegene wat God gekies het om getuies te wees, en wat tydens sy verskynings saam met Hom geëet en gedrink het. In Johannes 14:21 en 22 pas die 3a-komponent, maar ook die 3c-komponent van $\dot{\varepsilon} \mu \phi \alpha \nu i \zeta \omega$, in 'n metaforiese sin gebruik van Jesus wat Homself op geestelike wyse sal laat sigbaar word vir of kennis van Homself sal meedeel aan diegene wat sy gebooie bewaar. 
Die opstandingsverskynings van Jesus het dus in al bogenoemde gevalle die betekenis van Homself laat sigbaar word aan net sy volgelinge. Dit gaan dus in Jesus se geval om 'n opstandingsliggaam wat nie vanself op natuurlike wyse sigbaar was nie en wat deur Hom sigbaar gemaak moes word. Die afleiding kan dus gemaak word dat sy verheerlikte opstandingsliggaam nie tot die gewone orde van natuurlike liggame behoort het wat vanself op 'n natuurlike wyse sigbaar was nie. Sy opstandingsliggaam het tot ' $n$ ander bestaanswyse behoort, en soos dit verder uit die Skrif duidelik word, tot dié van die ewige onverganklike bestaanswyse (vgl Botha 1991:81-86 vir 'n bespreking van die nuwe liggaamlike karakter van Jesus se opstandingsliggaam).

\subsection{Die aard van die opstandingsverskyning in Matteus 27:51b-53}

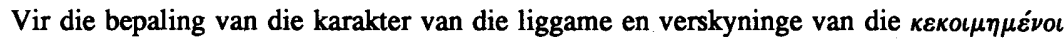
in Matteus 27:51b-53, moet die antwoord eerstens binne die konteks van hierdie gedeelte self gesoek word voordat vergelykings getref mag word met Jesus se opstandingsliggaam. en dié van ander persone wat deur Hom uit die dood opgewek is.

Hoewel die referensiemoontlikhede van die betekeniskomponente van $\sigma \hat{\omega} \mu \alpha$ in die Nuwe Testament or die algemeen baie wyduiteenlopend is, is die enigste betekenis van $\sigma \dot{\omega} \mu \alpha \tau \alpha$ in vers 53 wat pas by die konteks van Matteus 27 (die ander betekeniskomponente wat vir $\sigma \hat{\omega} \mu \alpha$ angegee word is 'kerk', 'slaaf' en 'realiteit', (vgl Louw \& Nida 1988b:240), dié van die fisiese liggaam van mense, diere of plante (lg slegs in 1 Kor 15:37 ter wille van die bepaalde analogie). Binne die konteks van Matteus 27:51b-53 gaan dit egter kennelik nie om die liggame van diere of plante nie, maar om dié van mense. In aansluiting by die letterlike betekenisgebruik van $\sigma \hat{\omega} \mu \alpha$ is daar ook 'n $f$ guurlike gebruik verwysende na 'n persoon self as 'n fisiese liggaam (vgl Louw \& Nida 1988a:39.8). Aangesien dit in Matteus 27 egter gaan om iets wat gebeur met die lewe-

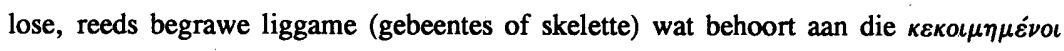
(die ontslapenes [vgl Louw \& Nida 1988a:\$23.104], 'n participium met naamwoordelike funksie wat die persoonlike aspek aandui van die ontslapenes met wie se liggame, onderskeie van hulleself as persone wat gesterf het, iets gebeur) word die figuurlike betekenisgebruik van $\sigma \omega \dot{\omega} \mu \alpha \tau \alpha$ hier deur die konteks uitgeskakel.

Die betekenis van die werkwoorde $\dot{\eta} \gamma \varepsilon \dot{\varepsilon} \rho \theta \eta \sigma \alpha \nu$, $\dot{\varepsilon} \xi \varepsilon \lambda \theta o ́ \nu \tau \varepsilon \varsigma, \varepsilon \iota \sigma \hat{\eta} \lambda \theta o \nu$ en

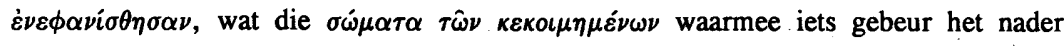
kwalifiseer, moet vervolgens nader bekyk word om te probeer vasstel wat presies met

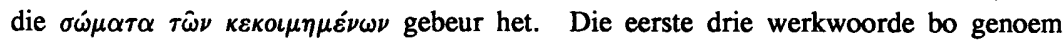

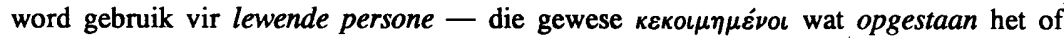
opgewek is, en nou as lewende persone handel - wat uitgaan uit die grafte en ingaan in die stad. Dit gaan dus nie om skelette wat soos marionette regop gehou en vertoon 
is nie en later weer begrawe is nie (deur wie!). Die verskillende betekeniskomponente

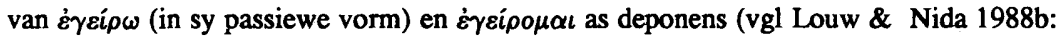
69; Du Toit 1989:326-327), afgegrens deur die semantiese veld van $\pi 0 \lambda \lambda \grave{\alpha} \sigma \omega \dot{\omega} \mu \alpha \tau \alpha$

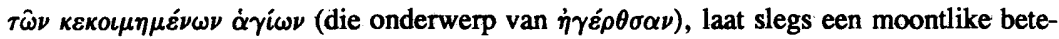
keniskomponent oop waarmee die onderwerp $\sigma \omega \dot{\omega} \mu \alpha \tau \alpha$ kan skakel, naamlik: 'to cause someone to live again after having once died - to raise to life, to make live again' (Louw \& Nida 1988a:323.94). Die werkwoorde $\dot{\eta} \gamma \varepsilon \dot{\varepsilon} \theta \eta \sigma \alpha \nu, \dot{\varepsilon} \xi \varepsilon \lambda \theta o ́ \nu \tau \varepsilon \varsigma$ en $\varepsilon i \sigma \hat{\eta} \lambda \theta 0 \nu$ is egter neutraal in betekenis ten opsigte van die bepaling of hierdie persone met hulle ou natuurlike liggame opgestaan het of met nuwe verheerlikte opstandingsliggame.

Die betekenis van die werkwoord $\dot{\varepsilon} \nu \varepsilon \phi \alpha \nu i \sigma \theta \eta \sigma \alpha \nu$ mag egter wel bepalend wees vir die aard van die verskyning van die opgestane persone om te bepaal of hierdie opstanding van die baie $\sigma \dot{\omega} \mu \alpha \tau \alpha$ van ontslape heiliges 'n opstanding na analogie van Lasarus of van Jesus se opstanding was. 'E $\mu \phi \alpha \nu i \zeta \omega$ het vier betekenismoontlikhede (kyk bo). By nadere ondersoek blyk dit dat komponent 3a op 'n sensoriese vlak lê, $3 b$ op 'n kognitiewe vlak, $3 c$ op 'n informatiewe vlak en komponent $3 d$ op 'n juridiese vlak.

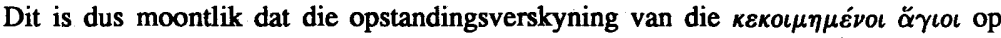
sintuiglike vlak deur die sigsintuig geskied het, of op die bewussynsvlak deur 'n bewuswording te laat plaasvind, of op 'n informatiewe vlak deur ' $n$ woordelikse mededeling, of op ' $n$ juridiese vlak vir getuienisdoeleindes (vgl Hand 23:15;22; 24:1; 25:2; 15; Heb 9:24; vgl Gundry 1982:577). Laasgenoemde betekeniskomponent het egter nie te doen met die hoe van die verskyning nie, maar met die doel daarvan en val hier buite bespreking.

Presies hoe die persone wat opgestaan het en hoe die baie toeskouers die gebeurtenis innerlik ervaar het, sou alleen deur die betrokkenes geopenbaar kon word. Die teks verskaf nie hierdie inligting nie. Belangrik vir die ondersoek is egter om te bepaal of

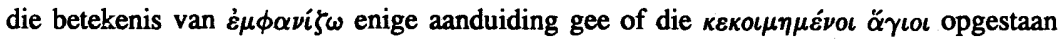
het met gewone natuurlike en dus sterflike liggame na analogie van die opstanding van Lasarus, of met verheerlikte onsterflike liggame soos Jesus gedoen het. Indien die liggame van die gestorwenes wat opgestaan het nie op 'n natuurlike wyse sigbaar was soos die geval met Lasarus, die seun van die weduwee van Nain en die dogtertjie van Jaïrus nie, dan is die enigste ander analogie wat oorbly vir die opstandingsverskyning van die кєкоц been' (Luk 24:39) nie op natuurlike wyse sigbaar was nie en deur Jesus, soos reeds bo aangetoon, sigbaar gemaak moes word.

'n Nadere ontleding van die betekenis van $\dot{\varepsilon} \mu \phi \alpha \nu i \zeta \omega$ sal moet antoon of die kausatiewe uitgang - $1 \zeta$ - sy kausatiewe betekenis behou het in al drie betekeniskomponente 3a tot 3c van $\dot{\varepsilon} \mu \phi \alpha \nu i \zeta \omega$ - wat aangetoon is as betekenismoontlikhede binne die 
semantiese veld van vers 53 . In komponent $3 a$ gaan dit om iets wat nie sigbaar is nie te laat sigbaar word, in $3 \mathrm{~b}$ om iets wat nie bekend is nie volledig bekend te laat maak, en in $3 \mathrm{c}$ om 'n saak wat nie algemeen bekend is nie te laat bekend word deur dit te vertel. In al drie gevalle is die kausatiewe laat-betekenis dus behou in die $\sin$ van iets wat nie vanself sigbaar of bekend is nie, te laat sigbaar of bekend word.

Indien gekies moet word watter van die drie moontlike betekeniskomponente die beste inpas by die semantiese veld van verse $51 \mathrm{~b}-53$, dan sou daarop gewys kan word dat komponent $3 \mathrm{a}$, soos bo angetoon, op die sintuiglike vlak lê en te doen het met sensoriese sigbaarmaking terwyl komponente $3 b$ en $3 c$ op die kognitiewe vlak lê van kennisoordraging. Die oorhoofse konteks hier het egter juis te doen met die aanskoulike, die skeuring van die tempelvoorhangsel, die aarde wat bewe, rotse wat skeur,

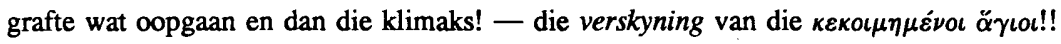
Die voorbeeld wat Louw \& Nida dan ook kies as 'n voorbeeld waar $\dot{\varepsilon} \mu \phi \alpha \nu i \xi \omega$ wel die 3a-betekenis het, is juis Matteus 27:53. Ongelukkig vertaal Louw \& Nida (1988a: \$24.19) die sinsnede met 'and they were seen by many people'. Die passiewe 'were seen by many people' aksentueer die aksie van die sogenaamde agens, die sienende toeskouers, en nie dié van die onderwerp, die sogenaamde lydende party in die passiewe

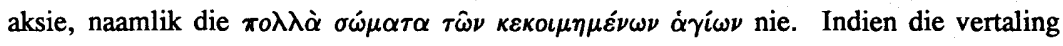
'they were seen' vervang sou word met 'they appeared' (soos bykans alle Engelse vertalings - vgl Vaughan 1967:119-120; 'verskyn' in Afrikaanse vertalings), dan sou die vertaling die kousatiewe betekenis van $\dot{\varepsilon} \mu \phi \alpha \nu i \zeta \omega$ in hierdie betrokke vers aksentueer. Dit kan gemeld word dat ook in sekulêre Grieks $\dot{\varepsilon} \mu \phi \alpha \nu i \hat{\zeta} \omega$ by religieuse gebruik in die aktief en medium aangewend word vir die betekenis 'to manifest oneself', 'to appear' (vgl [Bultmann] Lührmann 1974:7).

\section{GEVOLGTREKKING}

Die gedagte dat dit in Matteus 27:51b-53 gaan om 'n blote herlewing van mense op die suiwer natuurlike en dus outomaties sigbare vlak, soos in die geval van Lasarus, is vanuit eksegetiese oorwegings, voortvloeiend uit die teksgedeelte self, onaanvaarbaar. Hierdie eskatologiese en apokaliptiese gebeure was nie vanself sigbaar 'soos dit die geval was met die herleefde liggaam van Lasarus nie, maar moes deur God sigbaar gemaak word, geopenbaar word aan sekere inwoners van Jerusalem voordat hulle daarvan bewus geword het.

Indien dit dus aanvaar kan word dat ons hier 'n werklike liggaamlike opstanding het (vgl Hendriksen 1973:975; Calvyn 1972:212; Harris 1983:244; Brown 1969: 129), en nie slegs ' $n$ verskyning van liggame nie (Grosheide 1954:439), of 'n blote herlewing om later weer te sterwe nie (Ridderbos 1954:241), en dit plaasgevind het saam met die 
ander tekens terwyl Jesus aan die kruis gehang het, dan moet ons aan die verskyning van hierdie persone dink in dieselfde terme as aan die verskyning van die Here Jesus na sy opstanding, naamlik ' $n$ opstanding met verheerlikte liggame.

Dan kan daar, sonder om aan die punktuasie van die gedeelte te verander, of met ander verklarings te kom, aanvaar word 'that these saints were raised and left their tombs at the moment of Christ's death. Not until after Christ's resurrection did they enter Jerusalem and did they appear to many' (Hendriksen 1973:976). Dan is dit ook nie nodig om te vra of hierdie persone na hulle opstanding vanaf Vrydag in die grafte gebly het tot Sondag, die dag toe hulle aan mense in Jesusalem verskyn het nie (Calvyn 1972:212; Grosheide 1954:439). Na analogie van Jesus se opstanding sou dan ook veronderstel kon word dat die oopgaan van die grafte nie was ter wille van die uitlaat van die liggame van hierdie persone nie (vgl Botha 1991:88, Wenham 1981:152). Deur hulle opstanding, ook met verheerlikte opstandingsliggame soos Jesus, het ook hulle oorgegaan in dieselfde soort bestaanswyse as Jesus na sy opstanding toe Hy nie meer gebonde was aan die natuurlike beperkinge van die voor-opstandingsliggaam nie en $\mathrm{Hy}$ gedurende die veertig dae na sy opstanding by verskillende geleenthede verskyn en verdwyn het. Die aardbewing en die oopgaan van die grafte was dan nie ter wille van die liggame van die afgestorwenes om uit die nou oop grafte te kon kom nie, maar soos by die opstanding van die Here Jesus as 'n teken vir die lewendes, die teken van leë grafte! Die teken van lewendes wat nie meer by die dooies gesoek moet word nie (Luk 24: 5)! Die teken dat hierdie dooies liggaamlik met verheerlikte liggame opgestaan het

Vrae of hierdie mense Ou-Testamentiese vromes was en of hulle volgelinge van Jesus was wat op daardie stadium reeds gesterf het, hoekom Jerusalem 'die heilige stad' genoem word en waarom diegene wat opgestaan het eers ná die opstanding van Jesus aan mense verskyn het, is nie werklik ter sake vir die groot gedagte dat op grond van die voltooide versoeningswerk van Christus, hier reeds 'n opstanding van God se kinders met verheerlikte liggame plaasgevind het nie.

Dit kan dus gesê word dat met Jesus se uitroep: 'Dit is volbring!', en die gee van sy gees in die hande van die Vader (Joh 19:30; Luk 23:46), die versoeningswerk vir die volledige verlossing van die mens reeds volbring was, die opstanding reeds "n werklikheid geword het' (Hand 4:2), en dat dit saam met die skeur van die voorhangsel, die duisternis en die aardbewing, een van die tekens was wat die omvangryke teologiese betekenis van Jesus se kruisdood aangedui het, die inbreek van die nuwe eskatologiese wêreld in die ou wêreld (Schweizer 1975:515)! 


\section{Literatuurverwysings}

Arndt, W F \& Gingrich, F W 1957. A Greek-English lexicon of the New Testament and other early Christian literature. Chigaco: University of Chigaco.

Botha, S P 1991. Opstanding, opstandingsliggaam en opstandingslewe volgens 1 Korintiërs 15:35-58. 'n Eksegetiese studie. Ongepubliseerde DD-proefskrif, Universiteit van die Noorde.

Brown, D 1969. The four Gospels. A commentary-critical, experimental and practical. Edenburgh: Banner of Truth.

[Bultmann, R] Lührmann, D 1974. s v $\dot{\varepsilon} \mu \phi \alpha \nu i \hat{\zeta} \omega$. TDNT.

Calvin, J 1972. A harmony of the gospels Matthew, Mark and Luke, and the epistles of James and Jude, Vol 3. Ed by Torrance, D W \& Torrance T F, tr by A.W Morrison. Grand Rapids: Eerdmans.

De Boor, W 1973. De Apostelgeschichte. Wuppertal: Brockhaus. (Wuppertaler Studienbibel.)

De Villiers, J L 1977. Die handelinge van die apostels, vol 1. Kaapstad: N G KerkUitgewers.

Du Toit, A B 1989. Primitive Christian belief in the resurrection of Jesus in the light of Pauline resurrection and appearance terminology. Neotestamentica 23/2, 309330.

Grosheide, F W 1954. Het Evangelie naar Matthelis. Kampen: Kok. (KV.) 1962. De handelingen der apostelen. Kampen: Kok. (KV.)

Gundry, R H 1982. Matthew: A commentary of his literary and theological art. Grand Rapids: Eerdmans.

Guthrie, D 1970. New Testament introduction. Leicester: Intervarsity Press.

Harris, M J 1983. Raised immortal and resurrection immortality in the New Testament. Grand Rapids: Eerdmans.

Hendriksen, W 1973. The Gospel of Matthew. Edinburgh: Banner of Truth. (NTC.) Hill, D 1972. The Gospel of Matthew. London: Marshall, Morgan \& Scott. (NCB.)

Lenski, R C H 1934. The interpretation of the acts of the apostles. Minneapolis: Augsburg Publishing House.

Louw, J P \& Nida, E A 1988a. Greek-English lexicon of the New Testament based on semantic domains: Introduction and domains, Vol 1. New York: UBS.

1988b. Greek-English lexicon of the New Testament based on semantic domains: Indices, Vol 2. New York: UBS.

Moloney, F J 1986. The living voice of the Gospel: The Gospels today. London: Darton, Longman \& Todd. 
Nida, E A, Louw, J P, Snyman, A H, \& Cronje, J v W 1983. Style and discourse. Cape Town: BSSA.

Nielsen, J T 1980. Het Evangelie naar Mattheuis, vol 3. Nijkerk: G F Callenbach.

Ridderbos, H 1954. Het Evangelie naar Matthelis, vol 2. Kampen: Kok. (KV.)

Riekert, S J P K 1982a. The narrative coherence in Matthew 26-28. Neotestamentica $16,118-150$.

1982b. Discourse analysis of the greek text of Matthew 14-28 - Addendum to Neotestamentica 16, 53-74.

Schweizer E 1975. The good news according to Matthew, tr by D E Green. Atlanta: John Knox.

Senior, D 1976. The death of Jesus and the resurrection of the holy ones (Mt 27:5153). $C B Q 38 / 3,312-329$.

Wenham, J W 1981. When were the saints raised? A note on the punctuation of Matthew xxvii.51-3. JTS 32/1, 150-152.

Witherup, R D 1987. The death of Jesus and the raising of the saints: Matthew 27:5154 in context, in Richard, K D (ed), Society of Biblical Literature: Seminar Papers 1987, 574-85. Atlanta: Scholars Press. 